\title{
Contracting Margins? Liquid International Migration in the Pacific
}

Des marges qui se rétrécissent? La migration dans les eaux du Pacifique

¿Margen cada vez más estrecho? Migración en aguas del Pacífico

John Connell

\section{(2) OpenEdition}

\section{Journals}

Electronic version

URL: https://journals.openedition.org/remi/12739

DOI: $10.4000 /$ remi. 12739

ISSN: $1777-5418$

\section{Publisher}

Université de Poitiers

\section{Printed version}

Date of publication: 1 October 2019

Number of pages: 107-123

ISBN: 979-10-90426-64-1

ISSN: 0765-0752

\section{Electronic reference}

John Connell, "Contracting Margins? Liquid International Migration in the Pacific", Revue européenne des migrations internationales [Online], vol. 35 - $n^{\circ} 1$ et 2 | 2019, Online since 01 January 2021, connection on 16 April 2022. URL: http://journals.openedition.org/remi/12739 ; DOI: https://doi.org/ 10.4000/remi. 12739 


\title{
Contracting Margins? Liquid International Migration in the Pacific
}

\section{John Connell ${ }^{1}$}

\begin{abstract}
Migration has had a long history in the Pacific, with Pacific islanders sometimes regarded as particularly mobile people, within a sea of islands that covers a third of the planet (Hau'ofa, 1994). In the last half century, there has been both accelerated international migration, especially from the smaller Polynesian and Micronesian states, and rural-urban migration, with declining populations in national peripheries and growing high density urban concentrations. Migration has taken increasingly diverse forms, as it has gone from temporary to more permanent, unskilled to skilled and organized by households and governments. That increased flexibility, diversity and also individualization, and the uncertainty and instability that is attached to this, despite more open options, can be seen as a form of "liquid mobility" (Kymlicka, 2015): an apt phrase in an island realm. It is argued here that even in some of the most remote islands in the world the rationale, outcomes and consequences of migration are not necessarily distinctive, but epitomise two themes of "liquid mobility" hitherto more evident in Europe: distinctions between permanent and temporary migration are breaking down, with outcomes of varying precariousness, and this is undesirable for solidarity and equity. Liquid migration has followed more flexible labour markets, looser family relationships, cheaper travel and legal restrictions on permanency. Critically, these trends have accompanied slow economic growth in the region, the inability to create adequate numbers of jobs in the formal sector, steady population growth and rising expectations of what constitute adequate lives and livelihoods. While migration has long been primarily an economic phenomenon, social, political and environmental factors are also significant, and climate change will intensify future pressures for migration.
\end{abstract}

This overview focuses on the smaller islands, where economic opportunities are particularly limited and environmental challenges are mounting, to examine the opportunities and constraints that have influenced contemporary development and migration, and which offer a microcosm of broader changes in the region, where migration is one part of a wide-ranging deterritorialisation (Connell and Corbett, 2016). It further emphasises the three states in the region that are entirely composed of atolls, Kiribati, Tuvalu and the Marshall Islands, where vulnerability to both economic and environmental threats is substantial, 
where migration is increasingly important and the margins of settlement are fading.

\section{Development Challenges}

Migration is a function of development, disadvantage and opportunity. Within the Pacific region enormous differences exist between those Pacific island states (PICs) with very high population densities - on less fertile land as in the atoll states (notably 390 people per sq km in Tuvalu) compared with the much lower densities in the larger, high island, Melanesian states of Papua New Guinea (PNG) (with twenty people per sq km), Solomon Islands and Vanuatu. Average annual population increase in the PICs is around $2 \%$ but this varies widely. It is greatest in Melanesia, reaching 2.2\% in PNG, and lowest in Polynesia and Micronesia, where the impacts of international migration are significant, and several states have falling populations.

Fertility rates remain relatively high in most PICs, resulting in large numbers of young people who require education, training and job opportunities, while high teenage fertility rates are linked to poor education and unemployment. Creating employment is a regional priority. There is extreme competition for jobs, high levels of youth unemployment that have contributed to social tensions in some urban centres and pressures for migration. In most PICs, more than half the population are aged below twenty-four. Relatively few people by number and proportion have post-school (tertiary) education and training, which leaves shortages for skilled positions, and potential migrants without the skills to access good jobs elsewhere.

An economic rationale for migration is partly a function of limited economic growth in the region, the outcome of significant and well-known constraints to economic development in small island states. Conventional economic development has been limited through a combination of factors including small populations, scarce resources, remoteness, fragmentation, susceptibility to extreme events (especially cyclones) in fragile environments, and vulnerability to external economic shocks, which have contributed to a distinctive dependence on aid and imports. Further constraints include high communication, insurance and energy costs, irregular international transport volumes (and uneconomic routes and loads), disproportionately expensive public administration and infrastructure, scarce local skills, problems of matching skills and jobs, limited domestic capital, small domestic markets and few opportunities for economies of scale. Entrepreneurialism is stifled by the lack of skills, capital and contacts, but also by scarce opportunities, beyond small-scale services. Public administration is costly and inefficient, and in most PICs, provision of services - especially transport - to remote areas has worsened rather than improved. Relatively generous overseas aid and remittances have not compensated for such cumulative disadvantages. These constraints have resulted in narrow export specialisation and market orientation, so that export prices and foreign exchange earnings can fluctuate considerably and alarmingly. Manufacturing is conspicuous by its absence and without backward linkages to the agricultural or fisheries sectors. Weak economic growth has meant that the numbers of school-leavers, and thus potential entrants to the workforce, exceeds the number of jobs created (Connell, 2013). 
Economic development has been disappointing in the more or less half century since independence. Agriculture has produced the bulk of exports for most PICs but in this century has proved more difficult under a regime of increasingly free trade. Fisheries offer existing and future prospects, dependent on international negotiations, while tourism offers options for some, set against the tyranny of distance and intervening opportunities that has resulted in tourism being trivial in the atoll states. High islands - that make up almost all of Melanesia (Fiji, PNG, Solomon Islands and Vanuatu) and Polynesia (Samoa and Tonga), though islands are smaller there, have more development opportunities than the more remote atoll states, where opportunities are particularly scarce.

Migration has largely been a response to perceived socio-economic inequalities, that in recent years have been accentuated by both a rise in expectations of incomes and living conditions and greater familiarity with circumstances in overseas countries. Changing aspirations, the increased necessity and desire to earn cash, a preference for regular employment, and distaste for agricultural work have gradually given migration a more obvious economic rationale: a movement in search of wage and salary employment, scarce or absent at home.

\section{Rural-Urban Migration and Urbanisation}

Rural-urban migration is now mainly a Melanesian phenomenon, but is also substantial in the three atoll states, and is something of an alternative to international migration, where that cannot be achieved. Towns and cities have grown rapidly in the years since independence, and most urban residents are in Melanesian cities and towns. Urban birth rates are high, and a growing proportion of urban residents are now of a second or higher generation with few ties to "home" areas and limited ability and will to return (Petrou and Connell, 2017). Population densities are highest in capital cities despite the active discouragement of urban migration and residence. Notions that Pacific islanders are or should be rural people have been difficult to displace (Connell, 2011).

Virtually since independence, urban populations have increased faster than those in rural areas, through a combination of rural-urban migration and urban fertility, posing challenges for planning, land use, water and sanitation, housing and general infrastructure, as well as the need for effective social, health and employment policies (Connell, 2013 and 2017b; Mecartney and Connell, 2017). This has resulted in "over-urbanisation" characterised by high unemployment rates (typified in a "youth bulge"), inadequate housing and services, alongside significant and intensified environmental problems. Social problems including ill-health, domestic violence, theft and alcohol abuse have become more significant. Land shortages are an accelerating urban and coastal phenomenon, alongside land tenure disputes and conflicts, resulting in increasing numbers of informal settlements on unsuitable land.

Throughout the region, greater pressure is being exerted on coastal resources: especially as populations increase, because of the desire for access to services, and to land suitable for development (whether for agriculture, tourism or infrastructure). All urban centres (outside PNG) are coastal, contributing to a "coastal squeeze" that has put pressure on water resources and agricultural land, led to the clearance of mangroves, polluted lagoons, reduced the habitat 
of coastal fisheries, and increased the potential for coastal erosion. As urban centres have grown, newer migrants and newer housing areas, often informal, have located in marginal sites that are vulnerable to hazard. Many urban residents have few sources of income, no legal residential status and no security of tenure, limited access to services and live at high densities, the combination of which poses social problems and health risks. Within parts of Tarawa and Majuro, population densities have approached those in Hong Kong. In fragile urban atoll environments especially, high population densities challenge water supply systems, sanitation, and waste management and present serious environmental management problems. Economic growth is too limited to mitigate or manage such problems, hence interest in international migration has consequently grown. The combination of high population growth rates and fertility, few employment prospects and inadequate living conditions emphasises the economic rationale for migration.

\section{International Migration}

Migration has long been a feature of Pacific existence, since nineteenth century "blackbirding", the initially forcible kidnapping of men, to work on plantations from Hawaii to Australia, and to mines, from Chile to Palau (e.g. Maude, 1981). It was particularly significant for the atolls where domestic opportunities were scarce. By the end of the nineteenth century, in remote atolls like those of Tokelau, "the idea of permanent migration, involving a severance of many ties with the home island and of seeking one's fortune elsewhere, is well established in [...] life and thought. For the past seventy years or so it appears to have been accepted that some of nearly every group of siblings must tahe ('emigrate') simply because the local resources are seen as insufficient" (Hooper and Huntsman, 1973, 403-404). Although most migration was temporary, it was already underpinned by the desire to benefit both the welfare of the migrants, and of family members who remained at home. Twentieth century migration was more localized in Melanesian plantations and, over time, to scattered mine sites, especially Banaba and Nauru. It remained only exceptionally permanent.

International migration effectively began in the 1960s, particularly from Samoa, after its independence in 1962, spurred by the global long boom, demand for employment and the arrival of jet transport, mostly to metropolitan states (New Zealand and the United States). Tonga soon followed, along with the Cook Islands. That relieved population pressure and initiated a modern phase of remittances back to the islands. Intendedly temporary, migration gradually became more permanent. With rare exceptions, such as the immigration that followed the late 1960s nickel boom in New Caledonia, a lack of intra-regional migration was indicative of limited island economic development.

This process resulted in Tonga and Samoa becoming dependent on remittance flows to a greater extent than almost any other country. So significant has international migration become that, in Polynesia at least, families created smallscale metaphorical "transnational corporations of kin", by seemingly allocating family members to different countries, while migration became so common it was part of a "culture of migration" where migration is normative and reflects economic imperatives (Connell, 2008). Over time acquiring marketable skills has played a valuable role in enabling migrants to gain better jobs, and migration 
has been of more evidently skilled migrants, such as teachers, health workers, and also sportsmen (Connell, 2009). Losses of skilled labour have become serious in several PICs, with especially small states losing disproportionately more skills than larger states. The loss of skilled workers has raised questions about whether migration constitutes both a brain drain of unacceptable proportions that hampers national development, and a brain-waste as some fail to gain commensurate employment in destinations. Limited return migration has not remedied this problem and remittances may not always compensate for skill drains.

Most migration has been of individuals and later families, moving to metropolitan states, especially New Zealand, and with many becoming permanent migrants. Several migrant generations now exist there and in other metropolitan states. By contrast international migration from PNG, Solomon Islands and Vanuatu is rare. That has partly resulted from different colonial relationships. Typically, migration has largely followed "colonial" lines, notably from much of Micronesia to the United States (enshrined in the Compacts of Free Association, when Palau, Federated States of Micronesia (FSM) and the Marshall Islands acquired independence) and from several Polynesian PICs to New Zealand. The three Compact states, Cook Islands and Niue all chose not to gain full independence since migration opportunities might has been lost. Conversely Kiribati and Tuvalu, and the Melanesian states, were latecomers to migration, without migration corridors to the United Kingdom, Australia or elsewhere. Nevertheless, migration from PICs gradually extended, diversified and became more skilled, with the same rationale but some new entrants, notably Tuvalu.

Structural circumstances have changed. Most PICs now benefit from some preferential arrangements, notably in New Zealand, whether permanent migration opportunities (the lotteries of New Zealand and the United States) or schemes for temporary employment (invariably in agriculture) and/or for training in particular activities. Since 2002, New Zealand has offered a Pacific Access Category, which allocates places to a range of Pacific island countries. It offers 1,100 places a year to Samoa, 250 places a year to Tonga and Fiji, and seventu-five to migrants from both Kiribati and Tuvalu, but applicants are only granted a visa if they receive a job offer from New Zealand, a significant constraint for atoll states like Tuvalu (Kagan, 2016b). Demand exceeds supply.

The outcome of these international migration flows has been a substantial population of Pacific islanders in the metropolitan states bordering the Pacific. Currently, almost a million Pacific-born people live elsewhere, compared with a resident population of about 11 million, three quarters of whom are in PNG. Second and third generations swell these numbers significantly. By 2010 some 850,000 people of Pacific ethnicity or ancestry lived in the four main Pacific Rim migrant destinations: New Zealand $(350,000)$, Australia $(150,000)$, USA $(300,000)$ and Canada $(50,000)$. Ultimately migration in search of superior livelihoods is a continuation of past practices, where jet planes are faster, more effective and travel greater distances than canoes. That is abundantly true of atolls and the atoll states. The demographic balance is shifting outwards. 


\section{Remittances}

Migration has had massive economic significance. Over generations migrants are well placed to contribute to development at home through their familiarity with needs, and remittances contribute both directly and indirectly to welfare and human capital formation. Remittances, whether from more or less permanent migrants, especially overseas, or from seasonal workers, are of enormous and growing importance, even in the smaller islands of Melanesia, where they have contributed to the emergence of a "singaut economy" (Rasmussen, 2015; Hayes, 1993; Wilson, 2013; Petrou and Connell, 2017). Both unskilled and skilled migrants sustain remittance levels at high levels, over long time periods, often more than twenty years, while skilled migrants may also provide advice ("social remittances") on education, health and other matters (Connell and Brown, 2004; Brown and Connell, 2015). Remittances have made a very significant contribution to improved housing and water supplies, better access to health and education, more modern forms of consumption, such as solar panels and generators, and small-scale services such as bars or petrol stations, small stores and taxis. Remittances have enabled some diversification out of agriculture, an increased flexibility of livelihood choices, and over time a reduction in both poverty and inequality (Brown, Connell and Jimenez, 2014). Remittances also support local organisations (especially churches) and local needs, such as recovery from cyclone damage and other hazards.

As international migration has become of greater significance, so remittance flows are larger, especially in comparison with aid flows, and more stable than other sources of national and household finance. Remittances compensate in the aftermath of crises and disasters, whether physical (especially cyclones) or economic, being counter-cyclical, in response to economic and environmental shocks (Le De et al., 2013). Growing recognition of the value of remittances has brought new institutional interest in managing flows and "harnessing" remittances for financing investment and economic growth. Remittances have become a new "development mantra" (Kapur, 2005), in a climate of aid fatigue, uncertainty about private investment, the extent of international migration and the propensity in some countries to train workers for migration. They constitute an effective, informal, family-based system of social protection for migrants' families. At the same time, they may help to sustain a "migration syndrome", while imposing sacrifices on migrants.

Remittances are such a substantial component of most small PICs that these microstates have been described as having MIRAB (Migration, Remittances, Aid and Bureaucracy) economies, an acronym first devised for Kiribati, Tuvalu, Tokelau and the Cook Islands (Bertram and Watters, 1985), but which is now more broadly relevant. Tonga and Samoa are within the top twenty countries in the world in terms of the contribution of remittances to gross domestic product (GDP). Sustained remittances are crucial for national development and are likely to become more important in the future, even in a global context of substantial opposition to international migration, as aid fatigue increases. 


\section{Atoll States}

The Pacific includes some of the most vulnerable islands and countries in the world, increasingly threatened by climate change. Rising sea levels and more intense storms and cyclones pose risks to coastal settlements, water resources, plants and human health (Connell, 2013). Low-lying atolls are prone to a range of hazards, from cyclones to tsunamis, and islanders are less easily able to mitigate such hazards in small islands, or, without high ground, retreat from them (Connell, 2015). More than 150 populated atolls are in the Pacific, with the three atoll states most at risk, being exclusively composed of atolls scattered over a vast expanse of ocean, and which have weak economies, restricting national ability to respond and cope domestically. Atoll states are particularly affected by the tyrannies of distance. Migration and resettlement within the Pacific region are limited, primarily because economic and employment opportunities are absent and appropriate, accessible land is scarce. Kiribati and, to a lesser extent, Tuvalu, unlike the Marshall Islands (and Tokelau), have no significant ex-colonial ties or overseas diaspora populations, hence have no "beachhead" populations overseas with whom to build migration bridges, and fewer assured sources of remittances.

The more distinctive problems of atoll states include intermittent water shortages, poor soils, and a "transport stranglehold" that has been a constraint to development, bypassing many atoll islands. The capital cities of Funafuti, Majuro and Tarawa, all now holding more than half the nations' populations, after substantial internal migration, are particularly at risk because of high-density, relatively poor migrant populations in low-lying, marginal coastal areas. In Tarawa urban problems have reached crisis proportions: a "perfect storm" of economic problems intensified by environmental changes and extreme pressure on scarce resources (Storey and Hunter, 2010). Continued rural-urban migration has increased the vulnerability of these urban islands, as physical changes (such as causeway construction and sand and gravel mining) further threaten the "natural" environment. Many such marginal areas have only been recently settled, hence the poor are more likely to be at risk, yet they are less easily able to cope.

The converse of the extremes of urbanisation in the atoll states is depopulation of the "outer islands", in itself a relatively new concept in the Pacific, as employment is scarce, skilled workers are reluctant to be posted there and service delivery is limited (Connell, 2013). Almost every Pacific atoll, other than the three urban centres, has lost population in this century. Both Tuvalu and Tokelau have declining populations. Where migration opportunities are blocked, for whatever reason, then livelihoods are actually threatened, as in the densely populated Carteret Islands in PNG (Connell, 2016). The present and future of atolls and atoll states is of particular consequence in the region, because of the significance of economic challenges, but also because of the imminence of anticipated environmental threats to livelihoods, with ongoing climate change.

While migration even in the atoll states remains primarily an economic phenomenon (Shen and Gemenne, 2011; Shen and Binns, 2012; Connell, 2016), environmental factors may gradually become more significant, especially if changes become catastrophic. Since 2015 cyclones in Vanuatu and Fiji, and 
volcanic eruptions in Manam (PNG) and Ambae and Ambrym (Vanuatu) have proved catalysts for migration. Tsunamis, as in the Solomon Islands in 2007 and Samoa in 2009, have had similar but more localised effects. Only uninhabited islets have already succumbed to environmental change yet climate change, by stimulating more frequent and more intense cyclones, is likely to be a factor in contributing to "slow onset" migration and quests for resettlement.

\section{Resettlement}

Past resettlement schemes in the region provide unpromising precedents. Resettlement programmes have existed in the Pacific at least since the 1900s when people from some FSM atolls were formally relocated on Pohnpei after cyclones. In the 1930s people from Kiribati were resettled in the Solomon Islands and in Fiji. These international movements, of people experiencing drought and reduced livelihoods, occurred within and between British possessions in colonial times. While the resettlement of Banabans in Fiji has been relatively successful, since an "empty" island without local claimants was available and at the time involved no more than about 1000 people, seventy years later, uncertainty still reigns over land tenure (Connell and Tabucanon, 2015). Otherwise most resettlement after environmental hazards, mainly volcanic eruptions and tsunamis (and also forced migration from military and mine sites), has been largely unsuccessful (Connell, 2012; Connell and Lutkehaus, 2017a and 2017b; McAdam, 2014) with migrants seeking to return home, land disputes intensifying, friction occurring with nearby people and challenges in adapting to different ecological zones and cultures.

Resettlement of Manam and Carteret Islanders in PNG, has been typically thwarted by "host" landowners, the impossibility of gaining adequate access to land and land rights and government inactivity, even after, in the case of the Carteret Islands, half a century of attempts, and in the case of Manam, urgent needs. Such relative failures in resettlement raise questions of citizenship, ethics and morality and bode poorly for future resettlement needs. The problems experienced by quite small populations moving short distances in similar cultural contexts are indicative of the potential future problems facing environmental migrants. Settlers have been perceived as outsiders and rival claimants to valuable coastal resources. Although Kiribati has purchased a small island in Fiji, for possible resettlement, the "welcome" that might be attached to migration of i-Kiribati is likely to be ambiguous.

Landowners have been increasingly reluctant to cede land to others, however moral and worthy their claims, even when they shared kinship ties or exchange relationships, especially as their own populations and needs have grown, and land has become more valuable. Neighbours are not necessarily friends. Without some significant political and cultural changes, there is little likelihood of effective resettlement within the Pacific region. The Carteret Islands and Manam are problematic precursors for the future of resettlement in the region. By contrast the resettlement of half the islanders from the Tokelau atolls, which was then experiencing cyclones and overcrowding, to New Zealand in the 1960s (Wessen et al., 1992), offers a more hopeful precedent for resettlement beyond the PICs themselves, albeit in colonial times. But international moves tend to be costly, risky, and require advance planning and political acquiescence and acceptability. 


\section{National Strategies?}

If most migration from PICs, other than rare resettlement schemes, has been independent of government involvement and intervention (or even facilitation), as migration became more obviously a development strategy, governments began to intervene to develop and regulate distant employment opportunities. That was spearheaded by Kiribati and Tuvalu, first in developing mining opportunities in Nauru, for most of the twentieth century, and subsequently, beginning in the 1960s, with the establishment of national Marine Training Schools to enable workers to acquire the skills needed to obtain employment on merchant shipping lines. In this century that briefly extended to cruise-ships providing employment opportunities for about 120 I-Kiribati women, between 2004 and 2012. Numbers were small and management was challenging (Kagan, 2016a) and the scheme eventually ended.

Kiribati and Tuvalu were unusual in training workers for migration as "seafarers", initially men and subsequently also women. That instituted the start of greater interest in, and a wider process of, training people for migration to achieve what the former Kiribati President, Anote Tong, called "migration with dignity", that is employment in occupations which enabled some degree of self-esteem and higher incomes, rather than low status, low income, entry-level positions, and are also likely to offer some permanency and prospects and enable a more substantial flow of remittances.

PICS without migration ties to metropolitan states have given increased attention to training workers for employment either overseas or at home. Vocational education has been upgraded in several countries. Two new initiatives in this century include the multinational Australia-Pacific Technical College (APTC) and the Kiribati Australia Nursing Initiative (KANI). The APTC enables Pacific islanders to gain Australian skills and qualifications in a variety of trade areas, that would enable better access to overseas labour markets, although in the first few years most graduates have remained in their home countries. KANI was a sectoral training scheme, where i-Kiribati nurses were trained in Australia, principally to remain there and generate remittances rather than transfer superior skills to Kiribati. It proved an extremely expensive programme, with doubtful benefits other than for the graduates, and was quite quickly cancelled, but international strategies have continued to evolve.

\section{Seasonal Worker Schemes}

Accompanying longer-term schemes for more formally skilled workers have been short-term temporary employment schemes introduced between PICs and Australia and New Zealand from 2007. Such schemes have been seen as potential prototypes that might be effective in addressing the need for migration as adaptation in the face of short term hazards and slow onset climate change.

Seasonal worker schemes in the Pacific were introduced in New Zealand in the 1960s, to give opportunities to Pacific islanders to work for short periods in agriculture and provide mainly harvest labour to farmers. However New Zealand faced substantial overstayer problems and the schemes were shortlived (Macpherson, 1981). A new Recognised Seasonal Employer (RSE) scheme began in 2007 and was followed in 2008 by a similar Australian SWP (Seasonal 
Worker Programme) scheme, both centred on the employment of agricultural workers for up to seven months in a year. New Zealand allows up to 9,500 migrant workers in a single year, and although Australia had no cap, numbers have been much lower. Most independent PICs have been involved; Tonga and Vanuatu have taken greatest advantage of them, whereas Tuvalu and Kiribati have only been marginally involved, disadvantaged by distance and transport costs, unfamiliarity and the difficulty of obtaining visas and passports, with potential workers lacking some basic skills, English language proficiency and the ability to develop workplace links necessary to smooth migration (Bedford et al., 2010).

New Zealand's RSE scheme has been seen as a success, for its role as a development initiative, and because access to income for Pacific Islanders is the cornerstone of a "triple win" scenario that benefits New Zealand, through filling labour shortages, benefits PICs, through the provision of employment, and benefits the RSE workers and their families. Distinct differences from the nineteenth century era of blackbirding are that demand exceeds supply and a growing number of workers are women (Connell, 2010). Australia provided rather fewer places, partly because it is more fragmented geographically and institutionally. The overall benefits have been mainly positive' despite some social costs (Gibson et al., 2014; Bedford and Bedford, 2010; Petrou and Connell, 2018). That the atoll states have largely failed to benefit emphasizes that risk and opportunities are unevenly distributed and that despite the needs of relatively poor countries and households, they are not the main beneficiaries.

These temporary negotiated transnational schemes are now expanding and extending into non-agricultural areas such as tourism, where there are similar labour deficits. In 2017 Australia introduced a microstate visa for northern Australia, specifically for Kiribati, Tuvalu and Nauru - the "orphan microstates" - to provide opportunities for up to 250 citizens (around fifty per year over five years). By early 2019 Pacific islander workers had been deployed in tourism (in Great Barrier Reef hotels), caring, forestry and meatpacking. Demand in these sectors will continue to grow and will not be met by domestic workers. A long history has accompanied the possibility of increased numbers of PIC (and other) migrants being involved in care giving at a time when the unsatisfied demand for care-givers is steadily increasing and a high proportion of all jobs in caring are held by new migrants from a range of "non-traditional" source countries (Negin et al., 2016). Small numbers and administrative problems are indicative of the constant underlying structural problems for small, remote nations engaging with distant and uncertain labour markets, especially where metropolitan countries are urged to "look after their own" and are distrustful of short-term migrants becoming more permanent (which caused the collapse of the 1960s schemes). However, unlike agricultural employment, vacancies are emerging in areas that require more skills beyond those currently held by most Pacific islanders, but are potentially more long-term.

On a regional scale, since most migration between Pacific island countries and metropolitan states has favoured Polynesian states (Samoa and Tonga) and, more generally, the states with colonial connections to New Zealand and the United States, and seasonal worker schemes favour countries that are not too distant from Australia and New Zealand, migration tends to proceed from 
inequality and contribute further to inequality. Atoll states have been particularly disadvantaged.

Promoting the migration of workers, long important for various Asian governments, has become of greater Pacific significance. In every case this is primarily designed to increase the flow of remittances, but raises questions over whether people are more valued as migrants or as citizens and more basic questions about the use of remittances and the alternatives to a focus on migration. Migration is not a development panacea and a judicious combination of policies is needed to effectively maximise the benefits, for households and for countries. This must be based on reciprocal relationships between countries and between places of origin and destination, while remittance flows must be balanced against the social costs of migration and the skill drain that may be involved. That is crucial in the atoll states where skilled human resources are scarce and migration appears ever more valuable.

\section{Conclusion}

Despite the growing significance of government intervention and regulation, throughout the PICs most migration is of islanders making their own decisions, and either moving into already overstretched urban centres or to cities overseas. Pacific people have used a multitude of strategies to achieve mobility: kinship, lotteries, the PAC, national agreements, temporary work schemes and simple illegal overstaying. Simultaneously government interventions in favour of migration (not always with dignity) have increased, and been oriented, at least by Australia, in a most recent phase, to the particular needs of very small atoll states. The value of remittances has shaped a substantial outward urge - at a time of aid fatigue and stagnant economic growth - that has drawn in PICs hitherto less involved with international migration. In the context of globalization and technological advancements, Pacific peoples are now more mobile than ever, travelling over greater distances and more frequently during their lives, partly a "liquid mobility" associated with the growing visibility of "floating populations" that stay temporarily (Engbersen, 2016). Environmental change is likely to enhance all these trends as the liquidity of migration increases further.

While the diversity of migration possibilities has increased, the legal rights and entitlements of Pacific island migrants have tended to decline - including the right to stay - exemplifying a new stratification and inequality within migration. Foreign migrants are all too likely to be seen as foreign workers on temporary visas, easily able to be replaced and removed and denied citizenship and residential status: a new precarity (Underhill and Rimmer, 2015; Petrou and Connell, 2017). Temporary agricultural workers are denied permanency but encouraged to return every year, in order to take advantage of their acquired skills, becoming "permanently temporary" and constantly floating, a situation that does nothing for equity, challenges the etymology of "guest" workers and may enhance domestic problems.

A quarter of a century ago when climate change was just beginning to be seen as a potential threat to low-lying Pacific islands, one geographer, in an article entitled "Earth's Empty Quarter", feared that at the end of the present century 
"almost all the descendants of today's Polynesian or Micronesian islanders will live in Auckland, Sydney, San Francisco and Salt Lake City. Occasionally they may recall that their ancestors once lived on tiny Pacific islands, [now] lonely Pacific islands, set in an empty ocean" (Ward, 1989: 245). While some islands all atolls - have been depopulated in the last century, it is a gloomy and unlikely prediction but it will take more effective policies and practices at several scales to ensure it does not become closer, and that, in Melanesia especially, urban concentrations are not excessive.

Atolls remain most at risk, but far from exceptional (Rallu, 1981; Connell, 1983), with atoll states characterised as weak and fragile where service delivery to remote areas and islands (where employment opportunities are usually particularly scarce) has worsened, resulting in selective and accelerated migration from outlying areas and outer islands. As long ago as 1954 Osborne (1966: 49) vividly recorded the "last days" of tiny Merir atoll (Palau): "the island is dying... the women are too old to cultivate taro in any quantity and the men cannot keep the coconut groves cleared". Other Palau atolls, such as Sonsorol, have effectively followed suit (Walda-Mandel, 2016) having failed to go from risk to resilience but chosen to leave a subsistence lifestyle for a more diverse and loosely modern livelihood. As aspirations increase, the human margins have gradually faded.

Land issues have constrained internal migration and resettlement throughout the Pacific region, and access to land is more difficult now than at any time in the past (other than in large private sector land grabs). Only Fiji offers some resettlement opportunities. Established local, regional and transnational networks ease processes of migration and settlement. Slow and steady migration and resettlement, the ability of the people themselves to participate in decision-making, the possibility of some people remaining at home and, in the end, the greater capacity of local people to resist displacement and mitigate environmental change, so the greater the chance of success. Yet there is always a danger of being too slow. Time and timing are of the essence. International migration is increasingly essential.

Demand for migration is likely to become more important in the future for a combination of social, economic and environmental reasons. PICs will need to maintain and develop strategies that most effectively benefit from all opportunities for migration, and to seek out other possible opportunities. Given the complex nature of the relationships between migration, climate change and socio-economic development, at various scales, a challenge for countries and the region as a whole is where best to focus policy (Connell, 2017a). Whatever forms of migration develop it is necessary to create an attractive political, social and economic environment that encourages migrants to remain in contact and be involved in their home countries and islands, to return and to remit and, if feasible, to make investments there. National strategies in the PICs are very slowly evolving in this direction. Yet, as migratory numbers and aspirations have grown, reaction to migration has become particularly strident, evident in Brexit and Donald Trump's call for a wall between the United States and Mexico, a lack of solidarity and empathy, highlighting the political ground-swell against globalisation, immigration alongside protectionism and virulent anti-immigration in Australia, marked by draconian policies towards refugees. In this 
century, Australia has tended to cut back its liberal provisions for migration from New Zealand, as that increasingly brought Pacific islander migrants who had first stayed in New Zealand and acquired citizenship there (Hamer, 2014). Concessional schemes for Pacific islanders have had no obvious place in Australia or the United States.

Migration has never been easy and there has rarely been a good time to be a migrant but the considerable extent of global opposition to migration seems unlikely to decline in the near future. Borders are hardening and legal restrictions are increasing, at the same time as both greater demand and support for temporary migration, where flexible labour markets offer neither stable nor well-pad jobs: the basis of liquid migration. It is in this context that the present and future of Pacific migration exists. On the margins especially, few opportunities exist for PICs and their residents to establish some degree of "migration with dignity" - where migration meets a range of needs and can be suitably planned and managed - but the politics of migration will become increasingly sensitive and critical. These issues are likely to become more challenging in the face of climate change, despite uncertainties about its future impact. If PICs can develop national economies where the "rush to migration" and population growth can be slowed, and harmful environmental change mitigated and reduced, migration strategies will be rather less urgent, and less likely to end in precarity. That does not seem imminent.

\section{References}

Bedford R and Bedford C (2010) International Migration and Climate Change: A Post-Copenhagen Perspective on Options for Kiribati and Tuvalu, in B. Burson Ed., Climate Change and Migration. South Pacific Perspectives, Wellington, IPS, pp. 89-134.

Bedford C, Bedford R and Ho E (2010) Engaging with the Recognised Seasonal Employer (RSE) work policy: The case of Tuvalu, Asian and Pacific Migration Journal, 19, pp. 421-445.

Brown R.P.C and Connell John (2015) Migration and Remittances: A Multidisciplinary Synthesis, in John Connell and R. Brown Eds., Migration and Remittances, Cheltenham Edward Elgar, pp. xiiv-Ixviii.

Brown R.P.C, Connell John and Jimenez E. (2014) Migrants' Remittances, Poverty and Social Protection in the South Pacific: Fiji and Tonga, Population, Space and Place, 20 (5), pp. 434-454.

Connell John (2017a) Migration and Climate Change:Towards a Secure Future, in R. Ketafono Ed., A Sustainable Future for Small States, London, Commonwealth Secretariat, pp. 323-362.

Connell John (2017b) A Tale of New Cities, Development Bulletin, 78, pp. 5-10.

Connell John (2016) Last Days in the Carteret Islands? Climate change, livelihoods and migration on coral atolls, Asia Pacific Viewpoint, 57 (1), pp. 3-15.

Connell John (2015) Vulnerable Islands: Climate Change, Tectonic Change, and Changing Livelihoods in the Western Pacific, The Contemporary Pacific, 27 (1), pp. 1-36. 
Connell John (2013) Islands at Risk. Environments, Economies and Contemporary Change, Cheltenham, Edward Elgar, 351 p.

Connell John (2012) Population Resettlement in the Pacific: Lessons from a Hazardous History, Australian Geographer, 43, pp. 127-142.

Connell John (2011) Elephants in the Pacific? Pacific urbanisation and its discontents, Asia Pacific Viewpoint, 52, pp. 121-135

Connell John (2010) From Blackbirds to Guestworkers in the South Pacific: Plus ça change... ?, Economic and Labour Relations Review, 20 (2), pp. 111-122.

Connell John (2009) The Global Care Chain. From the Pacific to the World, London, Routledge, 197 p.

Connell John (2008) Niue: Embracing a Culture of Migration, Journal of Ethnic and Migration Studies, 34, pp. 1021-1040.

Connell J (1983) The End Ever Nigh: Contemporary population change on Pitcairn Island, GeoJournal, 16 (2), pp. 193-200.

Connell John and Brown R.P.C. (2004) The Remittances of Migrant Tongan and Samoan Nurses in Australia, Human Resources for Health, 2 (2), pp. 1-16.

Connell John and Corbett J (2016) Deterritorialisation. Reconceptualising Development in the Pacific Islands, Global Society, 30 (4), pp. 83-604.

Connell John and Lutkehaus, N (2017a) Escaping Zaria's Fire? The Volcano Resettlement Problem of Manam Island, Papua New Guinea, Asia Pacific Viewpoint, 58(1), 14-26.

Connell John and Lutkehaus N (2017b) Environmental Refugees? A Tale of Two Resettlement Projects in Papua New Guinea, Australian Geographer, 48 (1), pp. 79-95.

Connell John and Tabucanon G (2016) From Banaba to Rabi: A Pacific Model for Resettlement?, in S. Price and J. Singer Eds., Global Implications of Development, Disasters and Climate Change, London, Routledge, pp. 91-107.

Engbersen G (2016) Floating populations, civic stratification and solidarity, Comparative Migration Studies, 4 (8), pp. 1-4.

Gibson J, McKenzie D and Rohorua H (2014) Development impacts of seasonal and temporary migration: A review of evidence from the Pacific and Southeast Asia, Asia and the Pacific Policy Studies, 1 (1), pp. 18-32.

Hamer P (2014) “Unsophisticated and unsuited": Australian barriers to Pacific Islander immigration from New Zealand, Political Science, 66 (2), pp. 93-118.

Hau'ofa E (1994) Our sea of islands, The Contemporary Pacific, 6, pp. 147-161.

Hayes G (1993) “Mirab囚 Processes and development on small Pacific islands: a case study from the southern Massim, Papua New Guinea, Pacific Viewpoint, 34, pp. 153-178.

Hooper A and Huntsman J (1973) A demographic history of the Tokelau islands, Journal of the Polynesian Society, 82 (4), pp. 366-411.

Kagan S (2016a) "On the ship, you can do anything": the impact of international cruiseship employment for I-Kiribati women, Pacific Studies, 36 (1), pp. 35-51. 
Kagan S (2016b) The Role of Remittances in Risk Management and Resilience in Tuvalu: Evidence and Potential Policy Responses, in A. Milan, B. Schraven, K. Warner and N. Cascone Eds., Migration, Risk Management and Climate Change: Evidence and Policy Responses, Cham, Springer, pp. 175-191.

Kymlicka W (2015) Solidarity in Diverse Societies: Beyond Neoliberal Multiculturalism and Welfare Chauvinism, Comparative Migration Studies, 3 (1), pp. 1-19.

Le De L, Gaillard J-C and Friesen W (2013) Remittances and Disaster: A Review, International Journal of Disaster Risk Reduction, 4 (4), pp. 34-43.

McAdam J (2014) Historical cross-border relocations in the Pacific: lessons for planned relocations in the context of climate change, Journal of Pacific History, 49, pp. 301-332.

Macpherson C (1981) Guest-worker movements and their consequences for donor and recipient countries: a case study, in G.W. Jones and H.V. Richter Eds., Population mobility and development: Southeast Asia and the Pacific, Canberra, ANU Development Studies Centre Monograph, 27, pp. 257-277.

Maude H. E. (1981) Slavers in Paradise; The Peruvian labour trade in Polynesia, 1862-1864, Canberra, ANU Press, 263 p.

Mecartney S and Connell John (2017) Urban Melanesia: The Challenges of Managing Land, Modernity and Tradition, in S. McDonnell, M. Allen and C. Filer Eds., Kastom, Property and Ideology. Land Transformations in Melanesia, Canberra, ANU Press, pp. 57-84.

Negin J, Coffman J, Connell John and Short S (2016) Foreign-born aged care workers in Australia: A growing trend, Australasian Journal on Ageing, 35 (4), pp. 13-17.

Nunn P (2013) The end of the Pacific? Effects of sea level rise on Pacific Island livelihoods, Singapore Journal of Tropical Geography, 34 (2), pp. 143-171.

Osborne D (1966) The Archaeology of the Palau Islands, Honolulu, Bishop Museum Bulletin, 230, $182 \mathrm{p}$.

Petrou K and Connell John (2018) "We Don't Feel Free At All". Temporary Ni-Vanuatu Workers in the Riverina, Australia, Rural Society, 27 (1), pp. 66-79.

Petrou K and Connell John (2017) Rural-urban migrants, translocal communities and the myth of return migration in Vanuatu: the case of Paama, Journal de la Société des Océanistes, 144-145, pp. 51-62.

Rallu J-L (1981) La dépopulation des archipels du Pacifique. L'exemple de quatre villages de l'île Malekula, Population, 3, pp. 519-540.

Rasmussen A (2015) In the Absence of the Gift. New Forms of Value and Personhood in a Papua New Guinea Community, New York, Berghahn, 199 p.

Shen S and Binns T (2012) Pathways, motivations and challenges: contemporary Tuvaluan migration to New Zealand, GeoJournal, 77, pp. 63-82.

Shen S and Gemenne Francois (2011) Contrasted Views on Environmental Change and Migration: the Case of Tuvaluan Migration to New Zealand, International Migration, 49, pp. 224-242.

Storey D and Hunter S (2010) Kiribati: an environmental perfect storm, Australian Geographer, 41, pp. 167-181. 
Underhill E and Rimmer M (2015) Itinerant Foreign harvest Workers in Australia: The Impact of Precarious Employment on Occupational Safety and Health, Policy and Practice in Health and Safety, 13 (2), pp. 35-46.

Walda-Mandel S (2016) "There is no place like home". Migration and Cultural Identity of the Sonsorolese, Micronesia, Heidelberg, Universitätsverlag Winter, $332 \mathrm{p}$.

Wessen A (Ed.) (1992) Migration and Health in a Small Society. The Case of Tokelau, Oxford, Clarendon Press, $447 \mathrm{p}$. 


\section{John Connell}

\section{Contracting Margins? Liquid International Migration in the Pacific}

In the smaller Pacific islands especially, migration has a long history. In this century international migration has become more significant in Melanesia, more diverse in terms of destinations and occupation, more valuable to national economies through remittances and more likely to be permanent. Governments of the smaller Pacific island states have become increasingly involved in negotiating migration strategies, as remittances have become more significant for national and household economies. Responding to scarce international opportunities has been particularly difficult in smaller, more remote states. In the coral island states outer islands are losing population. An economic rationale dominates migration but environmental changes are putting further pressure on the coral island states especially, and the margins of settlement in the Pacific are gradually contracting. Reversing these trends is unlikely to be imminent.

\section{Des marges qui se rétrécissent ? La migration dans les eaux du Pacifique}

En particulier dans les petites îles du Pacifique, la migration a une longue histoire. Au cours de ce siècle, la migration internationale est devenue plus importante en Mélanésie, plus diversifiée en termes de destinations et d'activités, plus précieuse pour les économies nationales grâce aux transferts de fonds et plus susceptible d'être permanente. Les gouvernements des petits États insulaires du Pacifique se sont de plus en plus impliqués dans la négociation des stratégies migratoires, les envois de fonds étant devenus plus importants pour les économies nationales et les ménages. II a été particulièrement difficile de saisir les rares occasions qui se sont présentées à l'échelle internationale dans les États les plus petits et les plus éloignés. Dans les États insulaires coraliens, les îles périphériques perdent leur population. La logique économique domine la migration, mais les changements environnementaux exercent une pression supplémentaire en particulier sur les États insulaires coraliens et les marges de peuplement dans le Pacifique se contractent progressivement. II est peu probable que l'on puisse rapidement renverser ces tendances.

\section{¿Margen cada vez más estrecho? Migración en aguas del Pacífico}

La migración tiene una larga historia, especialmente en las pequeñas islas del Pacífico. Durante este siglo, la migración internacional se ha vuelto más importante en Melanesia, más diversificada en términos de destinos y actividades, más valiosa para las economías nacionales a través de las remesas y con más probabilidades de ser permanente. Los gobiernos de los pequeños Estados insulares del Pacífico participan cada vez más en la negociación de estrategias de migración, ya que las remesas han adquirido mayor importancia para las economías y los hogares nacionales. Ha sido particularmente difícil aprovechar las pocas oportunidades internacionales que han surgido en los Estados más pequeños y distantes. En los Estados insulares de los corales, las islas periféricas están perdiendo su población. La lógica económica domina la migración, pero los cambios ambientales ejercen una presión adicional, particularmente sobre los estados insulares coralinos, y los márgenes de los asentamientos en el Pacífico se están reduciendo gradualmente. Es poco probable que estas tendencias puedan invertirse rápidamente. 